\title{
MORUS SPP. Material Conservation and Characterization and its Importance for Romanian Sericulture and GCEARS-PSP Development- A Review
}

\author{
Adela Ramona MOISE ${ }^{1}$, Liviu Alexandru MARGHITAS ${ }^{1}$, Otilia BOBIS ${ }^{2}$, Florina Maria COPACIU ${ }^{3}$ and \\ Daniel Severus DEZMIREAN ${ }^{1 *}$ \\ ${ }^{1}$ Department of Apiculture and Sericulture, University of Agricultural Science and Veterinary Medicine \\ Cluj-Napoca \\ ${ }^{2}$ Life Sciences Institute "King Michael I" of Romania, University of Agricultural Sciences and Veterinary \\ Medicine Cluj-Napoca \\ ${ }^{3}$ Department of Biochemistry, University of Agricultural Sciences and Veterinary Medicine Cluj-Napoca \\ *corresponding author: ddezmirean@usamvcluj.ro
}

Bulletin UASVM Animal Science and Biotechnologies 75(2)/ 2018

Print ISSN 1843-5262; Electronic ISSN 1843-536X

DOI:10.15835/buasvmcn-asb: 2018.0001

\begin{abstract}
Morus spp. is a perennial and woody plant, belonging to Moraceae family, genus Morus and is essential for sericulture. One of the main aims of Global Centre of Excellence for Advance Research in Sericulture and Promotion of Silk Production (GCEARS-PSP) is to create a reserve of Morus spp., to multiply the vegetal material and to provide it to farmers and also to create an important biotechnological support for further scientifically works. As in Romania the intensive plantations are almost non-existent, one of the main objective of the centre is to create a real base for sericulture revival (the existence of nutritional base for silkworms) and to develop the biotechnological scientific component of the centre.

The aims of this review are to create a clear overview of moriculture for sericulture and to reveal the biotechnological potential and pharmacological uses of different mulberry parts. In this review the major findings regarding description of Kokuso 21 variety, mulberry micropropagation and bioactive compounds of different vegetal parts from Mulberry spp. are presented, and represent only the first stage of the GCEARS-PSP activity.
\end{abstract}

Keywords: GCEARS-PSP, mulberry, conservation, bioactive

\section{INTRODUCTION}

Global Centre of Excellence for Advance Research in Sericulture and Promotion of Silk Production (GCEARS-PSP) (www.usamvcluj. ro/crcas-ppm) is located in UASVM $\mathrm{CN}$ and it is recognised by the International Sericulture Commission (http://www.inserco.org/) since 2014. The centre was created in order to achieve development of advanced research in sericulture and moriculture, to offer diagnostic services using modern techniques, to maintain and reproduce the gene pool of Romanian and foreign silkworm`s breeds and to promote the silk production.

Working in close collaboration with Laboratory of Bee's Products Control - APHIS, the GCEARS-PSP researches regards the biotechnological aspects of Morus spp. The most popular species of mulberry are Morus alba and Morus nigra, and Yongkang (2000) states that the intensive selection and mutation breedings have resulted in thousands of cultivars, hybrids and polyploids. Mulberry trees are valuable species not only for silkworm rearing, but also for gardening and landscaping, street shade and reduction of pollution level in the environment and soil (Rafati et al., 2011).

The purpose of the present review is to create a realistic image of the main GCEARS-PSP activities in the past and in the future regarding the moriculture. 
As it was stated by literature, the components of mulberry trees exhibiting their biological activity in the various pathological and health human ailments. Our research team want to draw the attention that mulberry is a source of potential indigenous nutraceuticals and functional food.

\section{Description of Kokuso 21 variety}

One of the main achievements of GCEARSPSP in 2017 was to set up a mulberry plantation in UASVM CN. This plantation was necessary for providing the vegetal material as food for the silkworms that the Department of Apiculture and Sericulture owns and material for the further biotechnological researches in moriculture (i.e., in vitro micropropagation, the extraction of biological active compounds, etc.). The mulberry from Kokuso 21 variety was purchased from Sericulture and Agriculture Experiment Station Vratza (Bulgaria) (http://ses-vratza.bacsa-silk. org), accompanied by phytosanitary certificate. The Sericulture Experiment Station (SES) in Vratza collects, characterizes and evaluates both indigenous and exotic mulberry varieties. Currently more than 140 mulberry accessions are maintained in the germplasm at SES-Vratza (Tzenov, 2002, cited by Weiguo, 2011). A number of 570 saplings were planted on 0.12 ha.

Kokuso 21 (Morus latifolia) has Japanese origins; it derives from the crossing between Naganua, Gariin and Shiso varieties and it is a bisexual variety.

In intensive type plantations it can produce from the first years a high quantity of leaves with high protein content. Kokuso 21 has a good development with long branches, large unlobed $(23 \mathrm{~cm} \mathrm{x} 17 \mathrm{~cm})$, thick and juicy nutritive leaves with slow withering. Leaves yield under rain fed conditions is higher than $15000 \mathrm{~kg} / \mathrm{ha}$ (http://sesvratza.bacsa-silk.org/en/chernichevi-fidanki).

FAO Electronic Conference on Mulberry for Animal Production (Morus1-L) states that "Ichinose" and "Kokuso 21" varieties have been used as parents for other varieties. One of the major reasons why "Ichinose" and "Kokuso 21" have been selected as parents is that "Ichinose" is female and "Kokuso 21" is male. They have desirable traits, and crossing is easy and simple.

Fertilization of M. alba Kokuso 21 with 120 $\mathrm{kg} \mathrm{N} / \mathrm{ha}$ applied in a large study described by
Papanastasis et al. (1995) was found very effective in increasing the production of this shrub.

Dolis et al. (2016) reported in leaves a general chemical composition, containing proteins $21.16 \%$, fat $3.54 \%$, crude fibre $17.88 \%$, nitrogen free extract $43.42 \%$ and ash content $13.96 \%$.

The biological and productive parameters of Kokuso 21, gived by Tănase (2007) are: number of branches/shrub - 24.6, branches length 115.2 $\mathrm{cm}$, branches thickness $15 \mathrm{~cm}$, internodes length $3.8 \mathrm{~cm}$, leaf surface $292.3 \mathrm{~m}^{2}$, leaf weight $6.2 \mathrm{~g}$, leaf production $3.0 \mathrm{~kg} / \mathrm{shrub} /$ series, leaves water content $75.73 \%$ and $25.45 \%$ protein content.

Even if the scientifically reports regarding Kokuso 21 variety are pretty poor, the existing studies presents very encouraging data, which made the decision of planting Kokuso 21 variety in our University, very easily.

\section{Mulberry micropropagation}

As we state in the introduction one of the goal of GCEARS-PSP is to create a reserve of Morus spp., and this aim will be reached by mulberry micropropagation.

The mulberry (Morus spp) is an important tree in the sericulture industry because its leaves represent the only source of food for Bombyx mori. Qualitative and quantitative improvements in mulberry varieties play a vital role in industrial advances. Unfortunately, the perennial nature of the plants, together with the species prolonged juvenile period, slows this process. Plant tissueculture techniques have been used extensively for the stock improvement. During the last forty years, several researchers (Chattopadhyay and Datta, 1990; Chitra and Padmaja, 2001; Hossain et al., 1990; Thomas, 2002) have reported success in plant regeneration from different explant types.

Mulberry has been micropropagated from many explants sources, such as sooth tips and axillary, isolated, or winter buds. The earliest reports, from Japan, include one from Ohyama (1970), who obtained the first complete plantlets from axillary-bud tissue. The majority of the research has involved in the use of MS (Murashige and Skoog, 1962) media for nodal cuttings, and for culture of axillary and apical buds. Other authors (Sharma and Thope, 1990) observed that an MS medium supplemented with $2.5 \mu \mathrm{M}$ BSA (bovine serum albumin) was optimum for in vitro-raised seedlings of Morus alba. Their explants exhibited 
significant differences in shoot-multiplication rates, and could be stored at $4^{\circ} \mathrm{C}$ for at least six months without any decrease in vigor. Rooting was enhanced by activated charcoal $(0.05-0.10 \%)$. Transplantation was $100 \%$ successful when the shoots were grown in a 1:1 sand-vermiculite mix in the greenhouse (Pattnaik and Chand, 1997). Thomas (2002) in a review presents the main researched on tissue culture in mulberry.

The success of shoot-culture experiments is highly influenced by the source and age of the explant, as well as the conditions under which it is cultured. Positioning of the explant also plays a crucial role in bud induction (Hossain et al., 1991). The same authors showed that, in the 10 studied genotypes, the maximum response of multipleshoot induction was obtained from subterminal buds (Hossain et al., 1992). They were able to produce multiple shoots from nodal explants of a 10 year old Morus leavigata tree. Shoot proliferation was higher when the BA level was raised to as much as $11 \mu \mathrm{M}$, but further increases suppressed development. The highest percentage of explants giving rise to shoots, and the maximum length of those shoots, was observed on MS media supplemented with $4.4 \mu \mathrm{M} \mathrm{BA}$, whereas the greatest number of shoots per explants was obtained from $11 \mu \mathrm{M}$ BA.

Paul et al. (2001) described a rapid in vitropropagation procedure, using for culture young axillaries buds, which were multiplied, rooted and transplanted to soil within 3 months.

When micropropagated plants are compared with those generated through cutting, the former have significantly higher vigor. Zaman et al. (1997) have assessed the field performance and biochemical analyses of both tissue culturederived plants and plants raised according to conventional methods. Their studies confirmed that micropropagated plants had significantly greater morphogenic vigor. The biochemical analysis of the leaves revealed no significant nutritional difference between the two types.

Survival rates for acclimatized plants varied from 75\% in Morus nigra (Yadav et al., 1990) up to 90-95\% in Morus nigra (Jain et al., 1992a, 1992b); Morus ihou, Morus cathayana and Morus serrata (Pattnaik and Chand, 1997) and Morus australis (Pattnaik et al., 1996). Sharma and Thrope (1990) transplanted Morus alba plants with $100 \%$ success.
An important progress has been made in mulberry improvement through tissue-culture techniques. Micropropagation procedures are already standardized in various Morus species, fact that provides good chances to GCEARS-PSP to realize new mulberry plants.

Anyway, more researches are still needed in the area of haploid and triploid plant production, somatic embryogenesis, etc. The attention should be focused on genetic engineering in mulberry. Judicious choice of the explant source, coupled with some refinements in media composition, should increase the success rate for recalcitrant genotypes. Improvements in regeneration ability and control of somaclonal variation are crucial for maximum exploitation of this genus. When more emphasis is paid to these research areas, the future of sericulture industry will be assured.

\section{Bioactive compounds of different vegetal matrices from Mulberry spp.}

Mulberry is exclusively used for rearing silkworm due to the presence of unique chemofactors like morin, $\beta$-sitosterol in leaves. Plant is a potential source for curing debilitating diseases. Flavonoids, anthocyanin and alkaloids present in the leaves, bark, root and fruits of mulberry play a pivotal role in containing free radicals and prooxidants generated in the body due to metabolism and phagocytosis (Ramesh et al., 2014).

Morus alba tree bark, fruits, and leaves have been used in conventional and natural medicine (China and India) for the treatment of diabetes, atherosclerosis, hyperlipidemia, hypertension, and more recently, some cancer and neurogenerative diseases (Butt et al., 2008). Mulberry leaves have been used for years to treat hyperglycemia, inflammation, cough, hypertension, cancer and fever (Kang et al., 2006). Because of its good therapeutic activity and low toxicity, Morus alba has been extensively used in conventional Chinese medicine (Li, 1998). Morus alba is reported to have neuroprotective, skin tonic, antioxidant, antihyperglycemic, antibacterial, antihypertensive and anti-hyperlipidemic activities (Nomura et al., 1980). Tables 1-3 present the general chemical composition of mulberry leaves. 
Table 1. The average values of the main constituents in mulberry leaves (According to Flaczyk et al., 2013)

\begin{tabular}{cccccc}
\hline Compound & $\begin{array}{c}\text { Concentration } \\
\mathrm{g} / 100 \mathrm{~g}\end{array}$ & $\begin{array}{c}\text { Phenolic } \\
\text { acids }\end{array}$ & $\begin{array}{c}\text { Concentration } \\
\mathrm{g} / 100 \mathrm{~g} \text { DW }\end{array}$ & Flavonols & $\begin{array}{c}\text { Concentration } \\
\mathrm{g} / 100 \mathrm{~g} \text { DW }\end{array}$ \\
\hline Water & 5.2 & Gallic & 0.02 & Rutin & 0.91 \\
\hline Protein & 14.70 & Protocatechuic & 0.16 & $\begin{array}{c}\text { Quercetin 3- } \beta-\mathrm{D}- \\
\text { glucoside }\end{array}$ & 0.54 \\
\hline Ash & 22.37 & p-hydroxybenzoic & 0.11 & $\begin{array}{c}\text { Kaempferol 3- } \beta-D- \\
\text { glucopyranoside }\end{array}$ & 0.32 \\
\hline Fat & 0.11 & Vanillic & 0.71 & Total Flavonols & 1.76 \\
\hline Succharose & 18.62 & Chlorogenic & 4.64 & & \\
\hline Glucose & 4.90 & Caffeic & 2.54 & & \\
\hline Fructose & 1.61 & p-coumaric & 0.27 & & \\
\hline Xylose & 0.85 & Ferulic & 0.39 & & \\
\hline Galactose & 0.27 & Sinapic & 0.21 & & \\
\hline $\begin{array}{c}\text { Other } \\
\text { carbohydrates }\end{array}$ & 17.04 & Total phenolic acids & 9.09 & \\
\hline
\end{tabular}

DW = dry weigh

Table 2. Antioxidant compounds and activity of mulberry leaves (according to Flaczyk et al., 2013)

\begin{tabular}{ccc}
\hline Compound & Unit & Value \\
\hline Total phenolics & g gallic acid equivalents/100g DW & 14.42 \\
\hline \multirow{2}{*}{ Ascorbic acid } & $\mathrm{mg} / 100 \mathrm{~g}$ of DW & 1.76 \\
\hline \multirow{4}{*}{ Antioxidant activity } & DPPH $(\mu$ Mol Trolox /g DW) & 214.08 \\
\cline { 2 - 3 } & ABTS $(\mu$ Mol Trolox /g DW & 51.76 \\
\cline { 2 - 3 } & Chelating activity $(\%)$ & $\begin{array}{c}29.88 \\
\text { for } 0.002 \mathrm{~g}\end{array}$ \\
\hline
\end{tabular}

DW = dry weight

Table 3. Bioactive compounds in mulberry fruits, according to Zhang et al. (2008)

\begin{tabular}{cccc}
\hline Phenolic compound & $\begin{array}{c}\text { Concentration } \\
\mu \mathrm{g} / \mathrm{g} \text { FW }\end{array}$ & Flavonoid & $\begin{array}{c}\text { Concentration } \\
\mu \mathrm{g} / \mathrm{g} \mathrm{FW}\end{array}$ \\
\hline Protocatechiuc acid & 14.66 & Taxifolin & 6.53 \\
\hline Chlorogenic acid & 24.72 & Rutin & 111.38 \\
\hline 4-CQA (CAE) & 7.32 & $\begin{array}{c}\text { Kamepferon- } \\
\text { hexoside }\end{array}$ & 20.80 \\
\hline 3,5-diCQA (CAE) & 7.99 & Quercetin & 3.29 \\
\hline Total & 54.68 & Total & 142 \\
\hline \multicolumn{2}{c}{ Total nonantocyanins phenolic (GAE) } & 653.2 \\
\hline
\end{tabular}

FW = fresh weight 
In the last period, wild food plants have become very attractive to the food industry, promoting their use as replacements for synthetic chemicals and nutraceuticals, in this way mulberry became a very important resource for its phytochemical composition, nutritional value and antioxidant properties.

As other authors done, Donno et al. (2014) identified mulberry as a rich source of antioxidant compounds; the observed fingerprint demonstrated that the species represent a rich source of phytochemicals, like organic acids, monoterpenes and polyphenolic compounds, especially flavonols and anthocyanins, which led to reasonably good overall fruit quality.

Among the bioactive compounds, one of the most important constituents of mulberry fruits is represented by anthocyanins (Lee et al., 2005). Several studies have investigated the content of phenolics as flavonoids and anthocyanins in mulberry extracts, as well as carotenoids content (Arabshdi-Delousee and Urooi, 2007).

Due to this health-promoting compounds mulberry fruits are traditionally used as a laxative, odontalgic, anthelmintic, expectorant, hypoglycaemic and emetic agent; the traditional Chinese medicine used mulberry fruit as folk remedy to treat oral and dental diseases, diabetes, hypertension, arthritis and anaemia (Liang et al., 2012).

Several researches investigated the nutraceutical properties of Morus spp. fruits, studying their nutritional potentials, but a complete profile with quality traits, phytochemical composition and antioxidant activity evaluation is still lacking. Previous studies have examined the total content of phenols, flavonoids, anthocyanins and antioxidant activity of Morus spp. grown in different regions (Chen et al., 2012; Ozgen et al., 2009; Uzun and Bayir, 2012), but total polyphenol content, antioxidant activity and most of the potential healthpromoting agents of mulberry fruits still remain under scribed.

Our research team has already started a chemical characterisation of Morus spp varieties. We started to analyze mulberry leafs and fruits, belonging to Morus nigra specie - Ukraina variety; using modern techniques for sugar spectrum, lipid, protein and mineral content, free aminoacid profile, polyphenolic and flavones contents and the methods are presented by Bobiş et al., 2018.
The high phenolic content and antioxidant activity of mulberry underline the nutritive and phyto-medicinal potential of this fruit. The results presented in this review indicate that Morus spp. has the potential to be further developed into a nutritionally and biotechnological valuable raw material for food and beverage application.

\section{CONCLUSIONS}

The recovery of Romanian sericulture is possible through the GCEARS-PSP actions. Its success depends on different factors, such as the production performances of mulberry plantation, obtaining high quality leaves for Bombyx mori feeding and rich mulberry leaves and fruits for production diversification.

A number of 570 mulberry trees (Morus latifolia) were planted in USAMV CN.

The literature study presented in this review, contains the characterisation of this plant, its leaves and fruits composition, bioactivity and their therapeutically effects on human are shortly presented here, but it demonstrates that the GCEARS-PSP has the ability to reach its economical and scientifically objectives.

Further studies will be done on the components of Kokuso 21 variety leafs and fruits in order to provide to the local pharmaceutical industry a very valuable vegetal raw material and to provide to the silkworms a quality fodder base.

\section{REFERENCES}

1. Arabshahi-Delouee S., Urooj A. (2007). Antioxidant properties of various solvent extracts of mulberry (Morus indica L.) leaves. Food Chemistry 102: 1233-1240.

2. Bobis, O., Dezmirean, D. S., Marghitas, L. A., Bonta, V., Urcan, A., Pasca, C., Moise, A.R. (2018) - Morus spp. for revigorating silkworm breeding in Romania and promoting health benefits of leaves and fruits. Book of Abstracts $9^{\text {th }}$ CASEE Conference, 6-9 June, Bucharest p. 7.

3. Butt, M.S., Nazir A., Tauseef Sultan M., Schroen K. (2008) - Morus alba L. nature's functional tonic. Trends in Food Science \& Technology, 19,505-512.

4. Chattopadhyay S., Datta S.K., (1990). A rapid clonal propagation of mulberry tree (Morus alba) through tissue culture. Proc $76^{\text {th }}$ Ind Sci Cong Part III (Abstr): 208-209.

5. Chen, S.K., Zhao P., Shao Y. X., Li Z., Zhang C., He X. (2012). Moracin M from Morus alba L. is a natural phosphodiesterase-4 inhibitor. Bioorganic \& Medicinal Chemistry Letters 22(9): 3261-3264. 
6. Chitra D.S.V., Padmaja G., (2001). Seasonal influence on axillary bud sprouting and micropropagation of elite cultivars of mulberry. Sci Hort 92: 55-68.

7. Dennis Thomas T. (2002). Advances in Mulberry Tissue Culture. Journal of Plant Biology, 45(1): 7-21.

8. Dezmirean D., L. Mărghitaş, (2013). Sericulture status, problems and developing strategies in Romania, Bulletin of UASVM CN, Animal Science Biotechnologies 70 (1): 1-8.

9. Dezmirean D.S., (2013). Curs de Biotehnologii în Apicultură și Sericicultură, Ed. AcademicPres Cluj Napoca.

10. Dolis M.G., Donose R., Simeanu C., Usturoi A., Raţu R. (2016). Research Regarding Chemical Composition of the Mulberry Leaves from Kokuso 21 Variety, AUO, Fascicula Ecotoxicologie, Zootehnie și Tehnologii de Industrie Alimentară, Vol. XV/A: 207-212.

11. Donno, D., Cerutti A. K., Prgomet, I., Mellano M. G., Beccaro G. L. (2015). Foodomics for mulberry fruit (Morus spp.): Analytical fingerprint as antioxidants' and health properties' determination tool, Food Research International 69:179-188.

12. Flaczyk Ewa, Kobus-Cisowska J., Przeor, M., Jozef Korczak, Remiszewski M., Korbas E., Buchowski M. (2013) - Chemical characterization and antioxidative properties of Polish variety of Morus alba L. leaf aqueous extracts from the laboratory and pilot-scale processes , Agri Sci, Vol.4, No.5B, 141-147.

13. Hossain M., Rahman S.M., Zaman A., Joarden O.I, (1990). In vitro propagation of mulberry from axillary bud culture. Raj Univ. St (B) 18:73-81.

14. Hossain M., Rahman S.M., Zaman A., Joarden O.I., Islam R. (1991). Effect of nature of explant and $\mathrm{pH}$ on in vitro propagation on some mulberry genotypes. Bull Seric Res 2: 13-22.

15. Hossain M., Rahman S.M., Zaman A., Joarden O.I., Islam R. (1992). Micropropagation of Morus laevigata Wall from mature trees. Plant Cell Rep 11: 522-524.

16. Jain, A.K., Datta RK, (1992a). Shoot organogenesis and plant regeneration in mulberry (Morus bombycis Koidz.): Factors influencing morphogenetic potential in callus cultures. Plant Cell Tissue Org Cult 29:43-50.

17. Jain, A.K., Datta RK (1992b). In vitro plant regeneration from excited cotyledons of Morus laevigata Wall. Ind J Seric 31:151-154.

18. Kang T.H., Hur J.Y., Kim H.B., Ryu J.H., Kim S.Y. (2006) Neuroprotective effects of the cyaniding- 3-0-bglucopyranoside isolated from mulberry fruit against cerebral ischemia. Neurosci Lett, 391: 168-172.

19. Lee J., Durst R. W., Wrolstad R.E., (2005). Determination of total monomeric anthocyanin pigment content of fruit juices, beverages, natural colorants, and wines by the $\mathrm{pH}$ differential method: collaborative study. J AOAC Int 88(5): 1269-1278.

20. Li L.N. (1998). Biologically active components from traditional Chinese medicines. Pure Appl Chem, 70: 547554.

21. Liang L., Wu X., Zhu M., Zhao W., Li F., Zou Y., Yang L., (2012). Chemical composition, nutritional value, and antioxidant activities of eight mulberry cultivars from China. Pharmacogn Mag. 8 (31): 215-224.

22. Machii H., Koyama A., Yamanouchi H.- Mulberry Breeding, Cultivation and Utilization in Japan. FAO Electronic Conference on Mulberry for Animal Production (Morus1-L).

23. Murashige T., Skoog F., (1962). A revised medium for rapid growth and bioassays with tabacco tissue culture. Physiol Plant 15: 473-497.

24. Nomura T., Fukai T., Kuwanon G. (1980). A new flavone derivative from the root barks of the cultivated mulberry tree (Morus alba L.). Chem Pharm Bull, 28: 2548-2552.

25. Ohyama K., (1970). Tissue culture in mulberry tree. Japan Agriculture Research Quar 5:30-34.

26. Ozgen M., Serce S., Kaya C., (2009). Phytochemical and antioxidant properties of anthocyanin-rich Morus nigra and Morus rubra fruits. Scientia Horticulturae 119 (3): 275-279.

27. Papanastasis, V.P., (1995). Results and researches carried out within the CAMAR EC/DG.VI Programme, contract 8001 -CT90-0030 titled "Selection and Utilization of Cultivated Fodder Trees and Shrubs in the Mediterranean Region".

28. Pattnaik S.K., Sahoo Y., Chand P.K., (1996). Micropropagation of a fruit tree, Morus australis Poir. Syn. M acidosa Griff. Plant Cell Rep 15: 841-845.

29. Pattnaik S.K., Chand P.K., (1997). Rapid clonal propagation of three mulberries, Morus cathayana Hemsi, M. Ihou Koiz and M. serrata Roxb. through in vitro culture of apical shoot buds and nodal explants from mature trees. Plant Cell Rep 16: 503-508.

30. Paul N., Mathew M.M., Thomas T.D. (2001). A rapid in vitro propagation procedure for mulberry (Morus alba $L$.). STARS 2: 31-38.

31. Rafati M., Khorasani N., Moattar F., Shirvany A., Moraghebi F., Hosseinzadeh S., (2011). Phytoremediatkion potential of Populus alba and Morus alba for cadmium, chromium and nickel absorption from polluted soil, Int. J. Environ. Res, 5(4): 961-970.

32. Ramesh, H.L., Sivaram, V., Yogananda Murthy V.N., (2014). Antioxidant and Medicinal Properties of Mulberry (Morus Sp.): A Review, WJPR 3 (6): 320-343.

33. Sharma, K.K., Thrope T.A., (1990). In vitro propagation of mulberry (Morus alba L.) through nodal segments. Sci Hort 42: 307-320.

34. Tănase Doina, (2007). The agro productive characterization of the mulberry varieties used in the amelioration programs. Lucrări ştiinţifice Zootehnie şi Biotehnologii, Timisoara, vol. 40(2),: 141-149.

35. Tzenov, P.I (2002) Conservation status of mulberry germplasm resources in Bulgaria. Paper contributed to expert consultation on promotion of global exchange of sericulture germ-plasm satellite session of 19th International Sericulture Congress, Bangkok, Thailand, 21-25 ${ }^{\text {th }}$ Sept 2002. http://www.fao.org/DOCREP/005/ AD107E/ad107e01.htm

36. Uzun H.I., Bayir A., (2012). Biochemical contents of mulberry (Morus spp.) fruits. Planta Med 78: 1. 
37. Yadav U., Lal M., Jaiswal V.S., (1990). Micropropagation of Morus nigra L from shoot tip and nodal explants of mature trees. Sc Hort 44:61-67.

38. Yongkang H., (2000). Mulberry cultivation and utilization in China. Electronic Conference on Mulberry for Animal Production (Morus 1-L), Rome, Italy, 11-43.

39. Zaman A., Islam R., Joarder O.I., (1997). Field performance and biochemical evaluation of micropropagated mulberry plants. Plant Cell Tiss Organ Cult 51: 61:64.

40. Zhang, W., (2008). HPLC-DAD_ESI-MS/MS Analysis and Antioxidant Activities of Nonanthocyanin Phenolics in
Mulberry (Morus alba L.). Journal of Food Science 73(6): 512-518.

41. Weiguo, Z., Venugopalan N., Chirakkara, Ercisli, S., Tsou, Chi-Hua, (2011). Morus. C. Kole (ed.), Wild Crop Relatives: Genomic and Breeding Resources, Tropical and Subtropical Fruits, DOI 10.1007/978-3-642-20447-0_5, Springer-Verlag Berlin Heidelberg.

42. www.usamvcluj.ro/crcas-ppm

43. http://www.inserco.org/

44. http://ses-vratza.bacsa-silk.org

45. http://ses-vratza.bacsa-silk.org/en/chernichevi-fidanki 